\title{
How to cease the 'succession' of anthropogenic environmental problems using the knowledge on their interconnected nature?
}

Sivakumaran Sivaramanan ( $\sim$ sivaramanansr@gmail.com )

IIC University of Technology https://orcid.org/0000-0002-9904-2977

Sarath Wimalabandara Kotagama

University of Colombo

\section{Research Article}

Keywords: Succession of environmental problems, man-made environmental problems, anthropogenic environmental crises, interconnected nature of environmental problems

Posted Date: September 10th, 2021

DOI: https://doi.org/10.21203/rs.3.rs-875471/v1

License: (1) (1) This work is licensed under a Creative Commons Attribution 4.0 International License. Read Full License 


\section{Abstract}

Some man-made environmental problems are in a succession. Usually this happens due to the establishment of unsustainable solutions to the identified man-made environmental crisis. When the human driven solutions to the environmental problem also become a threat, the chain continues as a succession of man-made environmental crises until a permanent sustainable or regenerative solution is achieved. For instance, in early 1950s, Dayak people suffered from malaria. World Health Organization (WHO) had permitted to spray huge amount of DDT to kill mosquitoes. The attempt was a success and vector borne disease malaria was mitigated, however, their houses began to fall down on their heads. This is because application of DDT also killed the parasitic wasp that had previously controlled thatch eating caterpillars. In this scenario the worst event is DDT poisoned insects were eaten by geckos, which were eaten by cats, the cats died (biomagnification of DDT) and the rat population increased. The people were affected by sylvatic plague and typhus. To find solution to this WHO was obliged to parachute 14,000 live cats into Borneo. Thus, to prevent this succession of man-made environmental crises a need for clear understanding on all man-made environmental issues and their causes and effects is required. This article reviews the previously published research paper "Keystone Links of Anthropogenic Environmental Problems and Emergence of Interconnected Man-made Environmental crises" on this journal. In that study 40 identified man-made environmental crises were mapped by their interconnections as causes and effects. And established concept map could be used in problem mitigation, or identifying most promising solution to the man-made environmental crises. Qualitative content analysis method was applied in that study, and 252 links between man-made environmental crises were identified and supported by real-world examples in the elaborated thesis.

\section{Introduction}

Most of the anthropogenic environmental problems depict the succession of problems, or expressly, when we try to solve one man-made environmental issue, the result would be a different man-made environmental problem, and this flow of varying man-made environmental crises continues inevitably. E.g., to solve pest outbreak agrochemicals are used. Agrochemicals cause water, soil, and air pollution. Here, one man-made environmental problem is replaced by another. And in some cases, this chain of problems continues as a succession. This is due to most of the anthropogenic solutions to the man-made environmental problem accompanied with another man-made environmental problem, which prevents finding a permanent or sustainable solution to the crises. Thus, it is clear there is a need for mapping of man-made environmental crises based on cause-and-effect relationship. When a complete map or concept diagram of all man-made environmental problems and their effects is revealed, that map can be used to prevent the occurrence of continuous succession of anthropogenic environmental crises. This is because, choosing the safe alternative solution by checking with the concept map the emergence of another man-made environmental problem could be prevented.

Records reveal that attempting to correct one environmental problem unknowingly created or exacerbated other environmental problems. For instance, after EPA has reduced the emission of particles larger than 2 
$\mathrm{mm}$ by $78 \%$ (1) as cited in (2), the air became clearer but it caused another problem of acid deposition in the region of north-eastern United States. This is because the larger particles in the emission were alkaline and it neutralizes the acidity caused by smaller sulphur oxide particles. And in the absence of alkaline large particles, smaller acid sulphur oxide accumulated in the air and leads to acid deposition. Mitigation to SOx also reduced the concentration of acid aerosol. This created another unexpected problem that the sulphuric acid aerosol also served as nuclei for the formation of clouds. More nuclei, smaller droplets were present. These droplets scatter incoming solar radiation before reaching the earth's surface resulting in dimming or global cooling effect. Absence of aerosol in the air intensified the impact of global warming (3) as cited in (2). In addition, aerosol particles are normally found in combustion emission along with manmade $\mathrm{CO}_{2}$, however, unlike $\mathrm{CO}_{2}$, aerosol particles have harmful effects on the human health. Due to this global mitigation of aerosol emission, China in particular has reduced the aerosol pollution by 2006 , as it peaked in the same year and caused severe respiratory health issues, and the global warming was accelerated (4).

Similarly, in early 1950s, Dayak people suffered from malaria. WHO had permitted to spray huge amount of DDT to kill mosquitoes. The attempt was a success and vector borne disease malaria was mitigated, however, their houses began to fall down on their heads. This is because application of DDT also killed the parasitic wasp that had previously controlled thatch eating caterpillars. In this scenario the worst event is DDT poisoned insects were eaten by geckos, which were eaten by cats, the cats died and the rat population increased. The people were affected by sylvatic plague and typhus. To find solution to this WHO was obliged to parachute 14,000 live cats into Borneo (5).

Similarly, invasive species of zebra mussel colonization was observed in the Lake Erie, which caused fouling and occupied all the pipelines, water intakes and outfalls. Control of these invasive species later became a success. However, it has been found that mussels increased the concentration of chemical contaminants through the entire aquatic food web in the lake and the associated waterways. It has been proved during the past industrial age many chemical effluents were disposed at Erie Lake, and the muscles consumes those sediments and recirculated the contaminants through the biological food chain. However, solutions to the first environmental problem are not mitigating the second. Similarly, in early 1980s selenium (heavy metal) toxicity caused biodiversity loss (death of cattails, algal blooms and decline in water fowl use) in Kesterson National wildlife refuge (6) as cited in (2).

Today water scarcity is an increasing global threat. To solve this there are more than 1600 desalination plants function all-over the world, and they produce more briny toxic sludge. A study revealed that for every litre of fresh water extracted, a litre and a half of salty chemical laden sludge (brine) is dumped into the ocean. When we consider the total brine emission of all present-day desalinisation plants that is enough to cover the state of Florida in a one food $(30 \mathrm{~cm})$ layer of slime $(7)$. Thus, solution to one anthropogenic crisis leads to another crisis. Today energy crisis is an increasing problem worldwide. Thus, energy efficient technologies are being implemented, such as substitution of LED bulbs instead of high energy consuming incandescent light bulb. Because LED bulb is $90 \%$ more energy efficient than the low-cost incandescent bulb. But LED bulbs has created another environmental problem while solving 
energy crisis. E-waste from LED bulbs contain toxic hazardous heavy metals such as arsenic, lead, mercury, and other metallic salts that contaminate the soil and water environment when it is not recycled safely.

According to Gerard Wynn (2014) (8), after the banning of Chlorofluorocarbon in 1987 Montreal Protocol, hydrofluorocarbons (HFC) are being used. Now the ozone depletion issue is getting solved, but the HFC has created another problem. HFC is 1000 times more potent greenhouse gas than the equivalent $\mathrm{CO}_{2}$. UN data on atmospheric HFC levels shown that annual HFC levels has grown rapidly by $10-15 \%$ annually from 2006-2010. Study further revealed that early phase-out of super climate gases such as HFC could stop release of 146 billion tonnes of $\mathrm{CO}_{2}$-equivalent by 2050 .

According to Hood (2019) (9) energy crisis leads to rise in oil prices in 1970s, this has boosted the production of biofuels from corn, sugar cane, and palm oil. Earlier use of biofuels believed as a solution to climate change because $\mathrm{CO}_{2}$ generated during the burning of biofuels would be partially offset by the $\mathrm{CO}_{2}$ absorbed by photosynthesis when the plants were growing. However, intensive farming of palm trees for biofuel causes severe deforestation in Indonesia and threatens the wildlife, such as deforestation encroached the habitats of orangutan. Scientists now estimated that twice the size of India would be needed to cultivate the biofuel plants to meet the global biofuel needs. This form of deforestation may severely intensify climate change and may occupies the remaining land allocated for food crops.

According to Hood (2019) (9), green solution for global energy crisis is wind farms. Globally more than 350,000 wind turbines generate more than $500 \mathrm{~kW}$ of emission free electricity. However, windfarms kill birds. Annually, 328, 000 birds (mostly nocturnal) killed or injured by fast spinning blades. It has been revealed in a study that wind farms in Western Ghats, India (UNESCO listed mountain range and forest) caused severe decline in predatory raptor bird population. In that region the predatory raptor birds found four times rarer than the adjacent areas. This has affected the food chain, where the population of prey fan throated lizard has been increased in the region, thus, this has become a crisis causing loss of biodiversity.

According to "www.scdhec.gov" (n.d.) (10), it has been estimated that globally 500,000 solar panels are installed every day. Report further stated that although solar panels provide a solution for global warming and providing a clean energy source, it has created hazardous heavy metal waste. Following data is given in the website, "Cadmium telluride (CdTe) solar panels may be a hazardous due to cadmium, gallium arsenide (GaAs) panels may be hazardous due to arsenic, some older silicon solar panels may be hazardous waste for hexavalent chromium coatings, newer, thin-film solar panels contain copper indium selenium (CIS) and copper indium gallium selenium (CIGS) and may be hazardous due to the presence of copper and selenium." Thus, solar panels have created heavy metal toxicity issue due to its hazardous waste while it is solving global energy crisis and global warming due to its clean energy. Author Guillaume Pitron in his book "Rare metals war" (published in 2018) has mentioned that toxic lakes in Mongolia is due to toxic leachate from these heavy metals of solar panels (9). A study on thin film solar panels (TFSPs) (11) revealed that corroded and degraded thin-film solar panels released toxic heavy metals 
pollutants such as zinc $(\mathrm{Zn})$, copper $(\mathrm{Cu})$, nickel $(\mathrm{Ni})$, gallium $(\mathrm{Ga})$, lead $(\mathrm{Pb})$, indium $(\mathrm{In})$ and chromium $(\mathrm{Cr})$ in to the soil and water. Besides, study also stated that release of metallic pollutants in soil can be increased in the acidic conditions.

\section{Literature Review}

Environmental systems are complex and interconnected (2). Present humans are experiencing the environmental problems that have not been experienced before in this century and they are manmade (2). In 1986 United States Environmental Protection Agency (USEPA) embarked on analyzing the risk caused by more than 30 environmental issues $(12,13)$ and subsequently United States National Research Council (USNRC) addressed these on the same basis as risk characterization $(14,15,13)$.

A "casual model" derived from (16) gives key characteristics of environmental problems such as persistence of the pollutant in the environment, the population exposed and health impacts. Vicky and coauthors (13) have also defined a sum of 18 specific descriptors to measure these characters.

In the UNEP (2012) report 21 issues were categorized based on the following criteria:

i. Issues that are critical to the global environment. Issues can be either positive or negative. But must be environmental in nature or environmentally related.

ii. Given priority over the next 1-3 years in the work programme of UNEP and/or other UN institutions and/or other international institutions concerned with the global environment.

iii. Issues have a large spatial scale, and they should be global, continental, or 'universal' in nature (issues that occur in many parts of the world).

iv. Issues that were recognized as 'emerging' based on newness, which can be the result of new scientific knowledge, new scales or accelerated rates of impacts, increased level of awareness and/or new ways to respond to the issues. 
Table 1

Environmental problems studied for interconnections

\begin{tabular}{|c|c|c|c|c|c|c|c|}
\hline $\begin{array}{l}\text { Overexploitation } \\
\text { of Natural } \\
\text { Resources }\end{array}$ & E1 & $\begin{array}{l}\text { Ocean } \\
\text { Acidification }\end{array}$ & E13 & Air pollution & E25 & $\begin{array}{l}\text { Human \& } \\
\text { Animal } \\
\text { Conflict }\end{array}$ & E37 \\
\hline $\begin{array}{l}\text { Vector-borne } \\
\text { diseases }\end{array}$ & E2 & Eutrophication & E14 & $\begin{array}{l}\text { Animal } \\
\text { Slaughter \& } \\
\text { Cruelty }\end{array}$ & E26 & $\begin{array}{l}\text { Poverty- } \\
\text { Disease- } \\
\text { Disability- } \\
\text { Inequality-War- } \\
\text { Food } \\
\text { insecurity }\end{array}$ & E38 \\
\hline $\begin{array}{l}\text { Global Energy } \\
\text { Crisis }\end{array}$ & E3 & $\begin{array}{l}\text { Groundwater } \\
\text { contamination- } \\
\text { depletion- } \\
\text { salinization }\end{array}$ & E15 & $\begin{array}{l}\text { Climate change } \\
\text { and Global } \\
\text { warming }\end{array}$ & E27 & $\begin{array}{l}\text { Nuclear } \\
\text { explosions- } \\
\text { radiation- } \\
\text { nuclear } \\
\text { wastes }\end{array}$ & E39 \\
\hline $\begin{array}{l}\text { El-Nino \& La } \\
\text { Nino }\end{array}$ & N4 & Oil spills & E16 & $\begin{array}{l}\text { Deforestation- } \\
\text { loss of } \\
\text { grasslands- sea } \\
\text { grass beds\& } \\
\text { mangroves }\end{array}$ & E28 & Agrochemicals & $\mathrm{E} 40$ \\
\hline $\begin{array}{l}\text { Biodiversity } \\
\text { Loss }\end{array}$ & E5 & $\begin{array}{l}\text { Plastic } \\
\text { pollution }\end{array}$ & E17 & $\begin{array}{l}\text { Coral } \\
\text { destruction \& } \\
\text { bleach }\end{array}$ & E29 & $\begin{array}{l}\text { Population } \\
\text { Explosion }\end{array}$ & E41 \\
\hline $\begin{array}{l}\text { Wetlands or } \\
\text { draining of } \\
\text { wetlands }\end{array}$ & E6 & $\begin{array}{l}\text { Thermal } \\
\text { Pollution }\end{array}$ & E18 & Ozone depletion & E30 & $\begin{array}{l}\text { Invasive } \\
\text { species or } \\
\text { Exotic species }\end{array}$ & E42 \\
\hline $\begin{array}{l}\text { Land } \\
\text { degradation- } \\
\text { sedimentation- } \\
\text { soil erosion }\end{array}$ & E7 & Solid waste & E19 & Acid Rain & E31 & $\begin{array}{l}\text { Intensive } \\
\text { farming }\end{array}$ & E43 \\
\hline $\begin{array}{l}\text { Pollution } \\
\text { through mining } \\
\text { activities }\end{array}$ & E8 & $\begin{array}{l}\text { Heavy metal } \\
\text { contamination }\end{array}$ & E20 & Light Pollution & E32 & Aquatic Weeds & E44 \\
\hline $\begin{array}{l}\text { Establishment } \\
\text { of Dams }\end{array}$ & E9 & Pests or weeds & E21 & $\begin{array}{l}\text { Noise \& } \\
\text { Vibration } \\
\text { pollution }\end{array}$ & E34 & & \\
\hline $\begin{array}{l}\text { Urbanization- } \\
\text { urban sprawl- } \\
\text { settlements }\end{array}$ & E10 & $\begin{array}{l}\text { Hazardous } \\
\text { waste }\end{array}$ & E23 & $\begin{array}{l}\text { Impacts of } \\
\text { biotechnology \& } \\
\text { Nanotechnology }\end{array}$ & E35 & & \\
\hline $\begin{array}{l}\text { Water Pollution } \\
\& \text { Water } \\
\text { Scarcity }\end{array}$ & E12 & E-Waste & E24 & Visual Pollution & E36 & $\begin{array}{l}\text { E11, E22 \&E33 } \\
\text { are not } \\
\text { available }\end{array}$ & \\
\hline
\end{tabular}

[N.B. - Numbers given to the man-made environmental problems (E\#\#) in the Table 1 (below) are given in brackets in the following part of the literature and discussion.] 
Man-made environmental problems are interconnected as causes and effects. UNEP report gave 21 emerging environmental issues for the $21^{\text {st }}$ century which were ranked based on their linkages to the various dimensions of sustainable development. These issues cut across major global environmental themes such as food production, food insecurity (E38), urbanization (E10), biodiversity (E05), freshwater (E12), marine (E13, E16, E17, and E18), climate change (E27), energy (E03), technology and waste (E19). In addition, report also concentrated on bridging the technology among countries, giving adequate funds or support to developing countries in order to combat the global environmental change and inclusive green economy. On 25 th of September 2015 at United Nation's sustainable development summit, 2030 agenda for sustainable development was developed with the participation of world leaders from over 150 nations. The seventeen Sustainable Development Goals (SDG) are aiming to end poverty (E38), end hunger (E38), ascertain good health (E38) and wellbeing, quality education, gender equality, clean water (E12) and sanitation, affordable and clean energy (E03), decent work and economic growth (E38), develop industry, innovation and infrastructure, reduce inequalities, establishing sustainable cities (E10) and communities (E41), ensure responsible consumption and production (E01), climate change (E27) and disaster risk, protecting aquatic life (E05, E16,E17, E29, E06, \& E18), protecting the life on land or secure the biodiversity (E05), democratic governance and peace building and establishing global partnerships to achieve these goals (17). Similarly, in the recent 2012 GEO 5 report, issues such as heavy metal toxicity (E20), invasive or alien species (E42), and water scarcity (E12) such as groundwater depletion (E15) were classified along with other modern issues. Two dozen of reports were reviewed by (18), included reports of National Research Council, EPA's Science Advisory Board, technical societies and research institutions.

In addition, according to the paper published by the Ministry of the Environment of Japan (2001), interconnected nature of several environmental problems such as overexploitation of natural resources, intensive farming, deforestation, energy crisis, urban sprawl, pollution (air/ fresh water, groundwater and marine), hazardous wastes, ozone depletion, soil degradation and acid rain were depicted (see figure 1).

\section{Materials And Methods}

Qualitative content analysis methodology was used. Major environmental problems were screened from published documents. And precisely 252 links were found. To validate the hypothesis, existence of all 252 links should be affirmed with the support of real-world examples collected from the reliable scientific literature. A concept diagram was created with the principles of the visualization tools of the Stockholm Environment Institute (SEI) of the United Nations Environment Manage-ment Group (EMG), which depicts a complete "mental map" of relationships among the man-made environmental problems. Data collection was done until the data saturation was achieved or when major categories showed depth and variation. As archival work, books, peer-reviewed journals, and papers from various sources including the internet was searched for relevant codes (links). The following diagram describes the functional flow of the qualitative content analysis methodology, see Fig. 2. Finally, keystone environmental problems were identified from the concept map based on the criteria given by the following approach. When mitigating a man-made environmental problem, if it results in the permanent disappearance of one or more man-made environmental problems, then that mitigated problem can be considered as a possible keystone man- 
made environmental problem, in a hypothetical situation where human adaptability factors such as economic, social, political, health, genetics, evolution and behavioural factors are absent (20).

\section{Results}

Man-made environmental problems are interconnected as cause and effect to one another. For instance, water pollution and water scarcity (E12) is caused by several other man-made environmental problems such as agrochemicals (E40), solid waste (E19), plastic pollution (E21), e-waste (E24), heavy metal contamination (E20), pollution through mining activities (E08), establishment of dams (E09), sedimentation and soil erosion (E07), over exploitation of natural resources (E01), hazardous waste (E23), intensive farming (E43), global warming and climate change (E27), groundwater contamination (E15), urbanization, urban sprawl and settlements(E10) and wetlands or draining of wetlands (E06). And the effects of water pollution (E12) are eutrophication (E14), biodiversity loss (E05) and disease and food insecurity (E38). The following concept map depicts the interconnected nature of 40 man-made environmental problems based on causes and effects relationship. After a prolonged study (from 2013 Dec. - 2019 Jan.) on real world evidences from inter connections between selected man-made environmental problems the following concept map was developed (22) See Fig. 3.

Similarly, causes of land degradation, desertification, and soil erosion (E07) are deforestation and destruction of mangroves (E28), agrochemicals (E40), pollution through mining activities (E08), overexploitation of natural resources (E01) (excess land usage), intensive farming (E43), heavy metal contamination (E20), water pollution and water scarcity (E12), establishment of dams (E09), invasive species or exotic species (E42) (e.g. Eucalyptus sp. causes land degradation through its oily litter). Similarly, impacts of land degradation, desertification and soil erosion (E07) are poverty, disease, disability and food insecurity (E38), in this group of problems, land degradation (E07) causes impacts such as food insecurity (E38) (while the disease and disability caused by famine or malnutrition are less pronounced) and biodiversity loss (E05) (poor soil no longer harbor organism and biodiversity). In the aforesaid scenario twelve environmental issues are directly linked to the land degradation, desertification and soil erosion (E07) (ten causes and two impacts).

\section{Discussion}

Based on the concept map in Fig. 3 now it is possible for us to check for possible resulting environmental problems when a solution is established. For instance, when we are mitigating energy crisis by using heavy metal containing photovoltaic cells, we can check the concept diagram (Fig. 3) for link between heavy metal contaminants and soil pollution or land degradation, water pollution, and biodiversity loss. Thus, use of the above concept map Fig. 3) in a computerized software system can simply indicate the list of possible environmental threats before implementing the proposed solution. Thus, it is possible for us to choose a sustainable to regenerative solution that are really safe to the nature and humankind, such as establishing a safe recycling mechanism for heavy metal components of photo voltaic cells when 
implementing the solar panels, or establishing class 3 landfills as in South Carolina, where the safer municipal solid wastes with non-hazardous solar panels are being disposed (10).

\section{Conclusion}

The concept map developed in the study could be used to analyze the man-made environmental problems that could emerge when establishing a proposed project. It has been evidenced that certain man-made environmental problems result in succession of anthropogenic environmental issues. Thus, use of concept map produced by this study may help the project designer to choose the best possible option where the emergence of resulted environmental problems, or succession of environmental crises is avoided, or minimized.

\section{Declarations}

\section{Acknowledgements}

Authors thank Central Environmental Authority of Sri Lanka for supporting them on this mission.

\section{Conflict of Interests}

There is no conflict of interest for this work.

-Ethical approval and consent to participate: Not applicable

-Consent for publication: Not applicable

-Availability of data and material: Data available through the following link: https://osf.io/pxnc8/? view_only=eb1a49fc5dd2416e8403a46d0ae827e2

and previously submitted paper "Keystone Links of Anthropogenic Environmental Problems and Emergence of Interconnected Man-made Environmental crises"

-Funding: Not Applicable

-Authors' contributions

All authors have read and approved the manuscript. Changes to the manuscript made and checked by both authors as guided by the review committee.

Dr Sivaramanan S: This paper is the outcome of the doctoral research. The data collection, literature writing, documentation for results, construction of concept map, analysis, finding key links and defining keystone environmental problems, drafting discussion and conclusion done by this author. This interconnected environmental problem was initiated with the development of a board game 'Enviropoly' 
(2017) then author converted the concept of his own game into a study with the support of the supervisor.

Prof. Kotagama SW: Professor guided and supervised this study. He played a major role as time to time discussed with the researcher (Dr. S. Sivaramanan) and suggested ways for improvements, professor also proof read and ameliorated the entire thesis document at the end of the study. Many grammatical and theoretical errors were corrected by him before the acceptance.

\section{References}


1. U.S.EPA. Strategic Plan for the Office of Research and Development. Final Report. ; 1996.

2. Committee on Research Opportunities and Priorities for EPA CoGEaRDoEaLSNRC.

Environmental challenges. In Building a Foundation for Sound Environmental Decisions.:

National Academies Press; 1997.

3. NRC. Aerosol Radiative Forcing and Climate Change. Washington, D.C.: National Research Council; 1996.

4. The Conversation. [Online].; 2013 [cited 20186 13. Available

from: http://theconversation.com/masking-and-unmasking-of-global-warming-by-aerosols19990.

5. Wahl DC. Designing Regenerative Cultures invites us to co-create thriving communities. In Wahl DC. Designing Regenerative Cultures. UK: Triarchy Press; 2016.

6. NRC. Irrigation-Induced Water Quality Problems. Washington, D.C.: National Research Council; 1989.

7. Hood. https://phys.org/. [Online].; 2019 [cited 202107 17. Available from: https://phys.org/news/2019-01-environment-solutions-problems.html.

8. Wynn. www.climatechangenews.com. [Online].; 2014 [cited 202107 20. Available from: https://www.climatechangenews.com/2014/05/13/banning-hfcs-from-2020-could-makebig-climate-impact-study/.

9. Hood. "www.phys.org". [Online].; 2019 [cited 202107 20. Available

from: https://phys.org/news/2019-01-environment-solutions-problems.html.

10. "scdhec.gov". [Online].; n.d. [cited 202107 20. Available

from: https://scdhec.gov/sites/default/files/Library/OR-1695.pdf.

11. Su LC, Ruan HD, Ballantine DJ, Lee CH, Cai ZW. Release of metal pollutants from corroded and degraded thin-film solar panels extracted by acids and buried in soils. Applied Geochemistry. 2019 Sep; 108: p. 104381.

12. USEPA. Office of Policy Analysis and Office of Policy. Plannibng and Evaluation. Unfinished buisness: A comparative assessments of environmental problems. Overview report and Appendices I-IV. Wachington :; 1987.

13. Vicky NB, William CC, Bhavik B, Mark KD, Jennifer MA, Chris NP, et al. International comparisopns of environmental hazards. In Jeanne KX, Roger KE. Global Environmental Risk. London: United Nations University Press and Earthscan Publications Ltd; 2001. p. 55-147.

14. Stern PC, Harvy V, Fineberg. Understanding risk: Informing decisions in a democratic society. Washinton. 1996.

15. USNRC. Science and judgement in risk assessment. Washinton. 1994.

16. Hohenemser C, Roger KE, Robert KW. "Casual structure." In Robert KW, Hohenemser C, Jeanne KX. Perilous progress: Managing the hazards of technology. Boulder, Colorado: Westview Press; 1985. p. 43-66.

17. UNDP. sustainabl edevelopment goals. [Online].; 2018. Available from: http://www.undp.org/content/undp/en/home/sustainable-development-goals.html.

18. Committee on Research Opportunities and Priorities for EPA CoGEaRDoEaLSNRC. Improving Our Understanding of Environmental Issues. In Building A Foundation for Sound Environmental Decisions.: National Academies Press; 1997. p. 13-36. 
19. "eanet.asia". [Online].; n.d. [cited 20187 11. Available

from: http://www.eanet.asia/product/e_learning/page1_2.html.

20. Mandal FB. http://ezinearticles.com. [Online].; 2010 [cited 201812 27. Available

from: http:// ezinearticles.com/? Interconnected-Environmental-Problems\&id=5337231.

21. Adu P. Understanding Qualitative Content Analysis.; 2017 [cited 202010 23. Available from: https://www.slideshare.net/kontorphilip/qualitative-content-analysis-for-systematicreviews.

22. Sivaramanan $\mathrm{S}$, Kotagama $\mathrm{S}$. Examine the interconnected nature of the man-made environmental problems in a global prospective. In 3rd World Summit on Climate Change and Global Warming (EuroSciCon Conference on Climate change); 2019; Courtyard by Marriott Prague Airport , Czech Republic: Euroscicon Ltd.

\section{Figures}

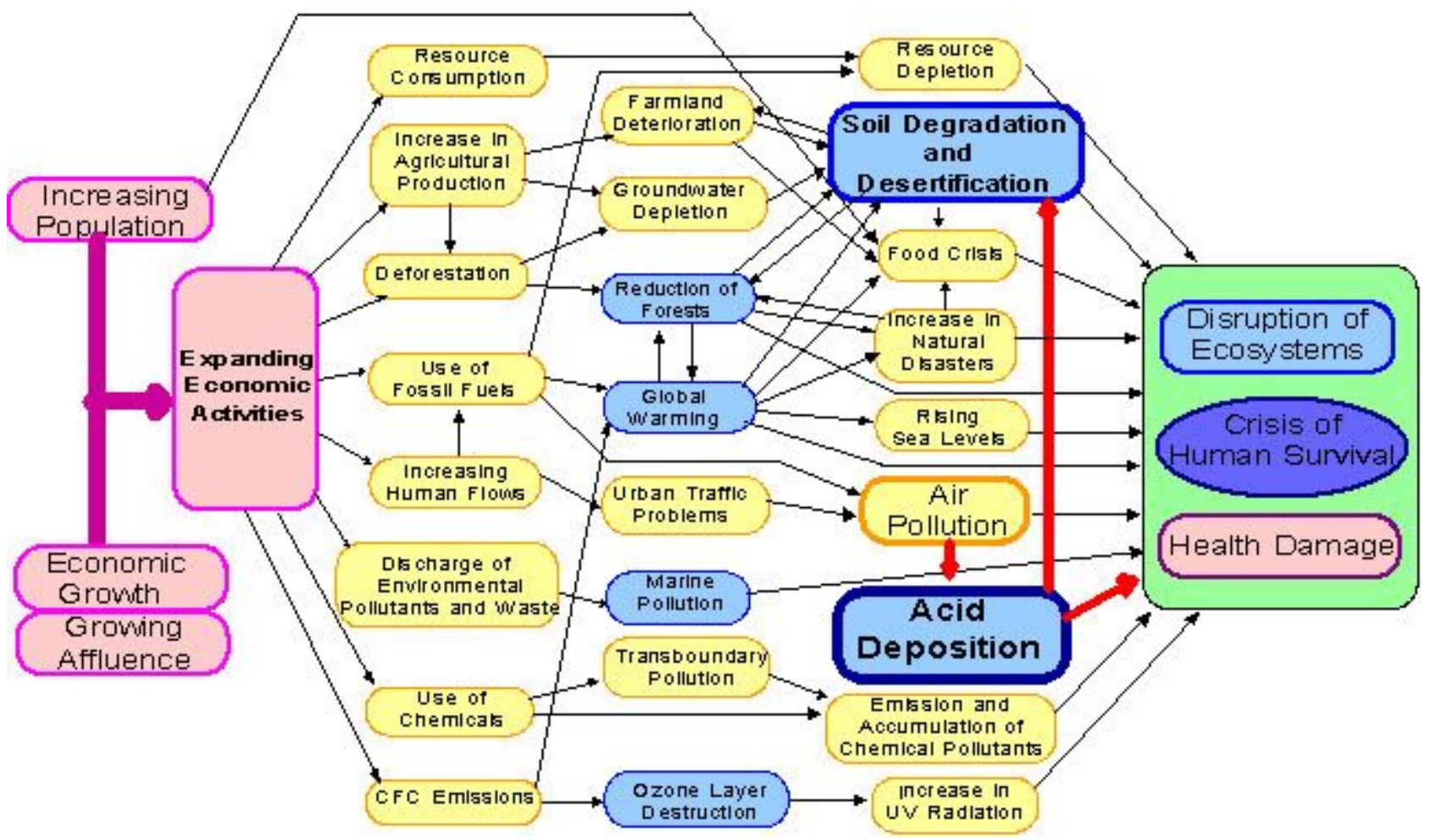

Figure 1

Global Environmental Issues as an Interconnected System Source: (19) 


\section{Basic Understanding of Content Analysis}

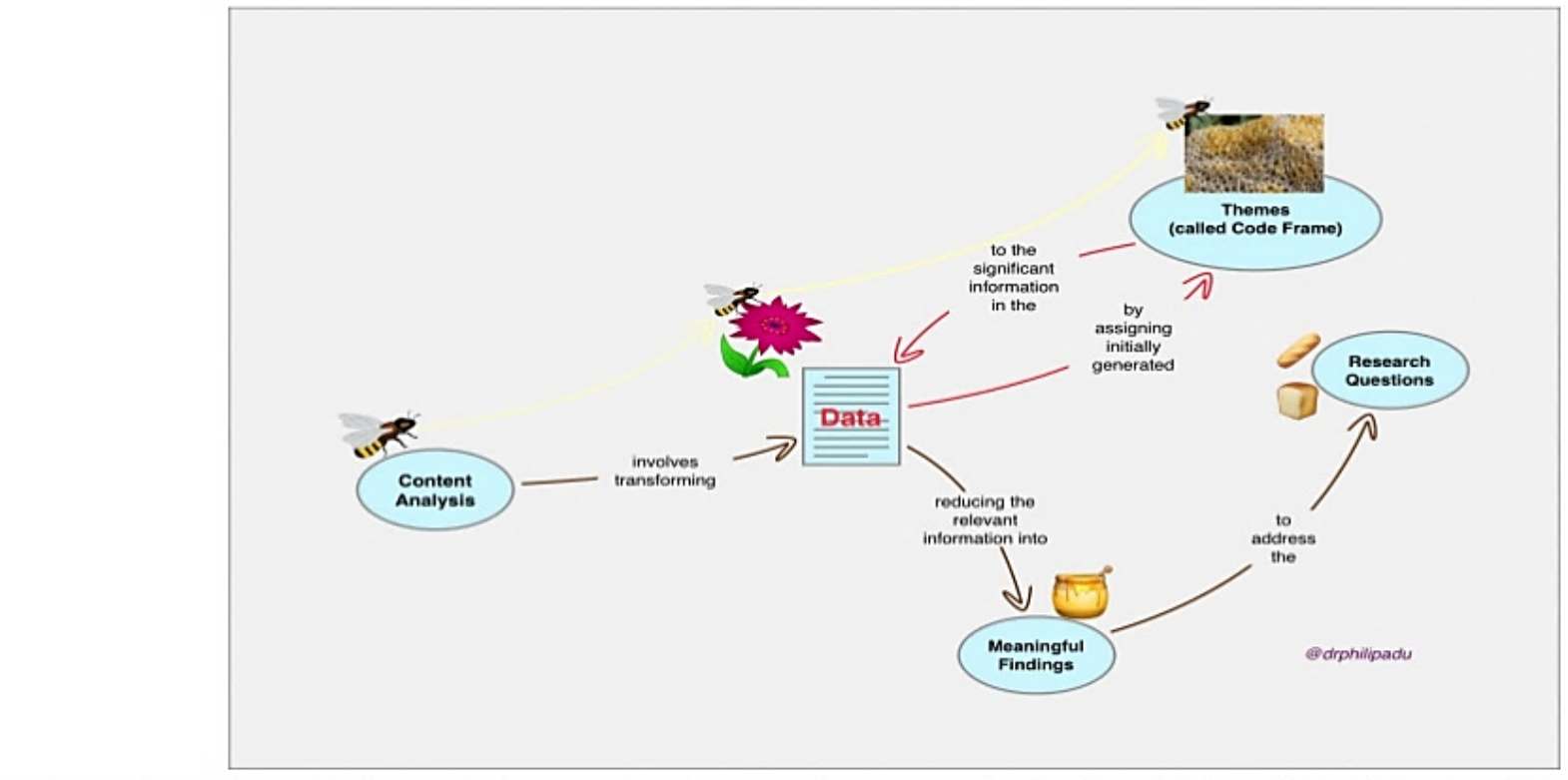

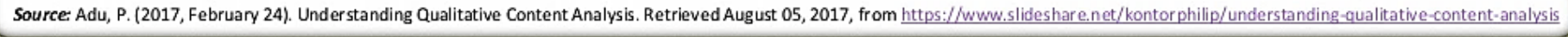

\section{Figure 2}

Qualitative content analysis methodology Source: (21) 


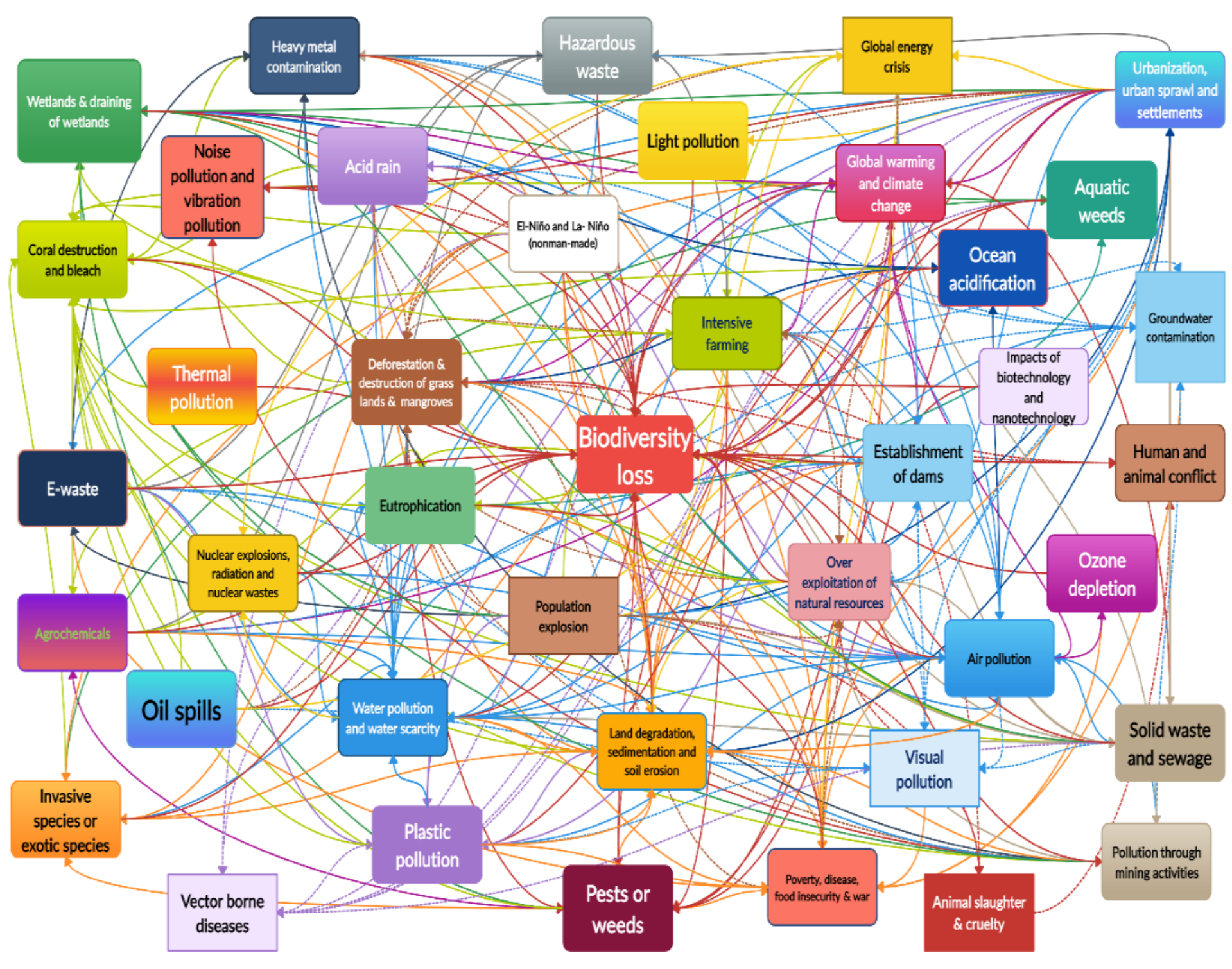

Figure 3

Concept map of interconnected man-made environmental problems based on cause-and-effect relationships 